Int.J. Hum. Soc. Dev. Res.

ISSN(P):2521-1439; ISSN(E):2523-4331

Volume 5, Number 1, 2021. 53-61

DOI: $10.30546 / 2523-4331.2021 .5 .1 .53$

\title{
COMMUNITY-BASED TOURISM FOR THE POTENTIALS ETHNIC FOOD OF NORTH SUMATRA
}

\author{
Saiful Anwar MATONDANG \\ Universitas Islam Sumatera Utara, Indonesia
}

Siti RAHMA

Universitas Islam Sumatera Utara, Indonesia

\section{Tashliyah HARAMAIN}

Universitas Islam Sumatera Utara, Indonesia

(C) The Author(s) 2021

\section{ABSTRACT}

Ethnic community affects the culinary tourism in the high competitiveness of the tourism industry. Ethnicity has made the shift the economic orientation of food tourism to the Community Based Tourism (CBT) paradigm. This research paper sought the growth of culinary tourism development and the ethnic food. A survey took 120 samples of ethnic food providers which boost the culinary tourism sectors in North Sumatra, Indonesia. Data obtained revealed that some ethnic groups created the local food recipes to produce many menus of restaurants, cafes, bakeries and e-commerce of start ups. Data showed that the use of ethnic food labels such as Malay, Mandailing, Karo, and Toba has made culinary tourism have great potent in future. It concludes that with culinary labeling products as ethnic food is one of the marketing strategies of food producers. The cuisines that already labeled as ethnic food are attracted to the emotions of customers to order them. It makes the ethnic food as a label in present marketing corresponding to new food products which have been put into the food business chains.

\section{C2021.All rights reserved.}

\section{ARTICLE HISTORY}

Received: 02/10/2020

Accepted:21/01/2021

Published online:30/04/2021

\section{KEYWORDS}

Ethnic food; tourism;

Culinary; community;

CBT 


\section{Introduction}

Tourism development has shifted from mere economic orientation towards strengthening the cultural Community. It makes the Community Based Tourism (CBT) a new model of the culinary industry Salazar (2012; Anuar \& Mohd Sood, 2017) and CBT provides a variety of ethnic food. Current paradigm of tourism sector has led the community development. The theme of tourism research oriented towards social environment sustainability by paying attention to the increasingly widespread application of information technology. Strengthening local identity with regional and global contexts (Matondang and Setiawan, 2015) gives rise to stronger cultural solidarity in various forms of cultural production, such as festival, fashion, and culinary performances in different cities in the world. The reality of Ethno-culture plurality (Giordano, 2015: 73) arises in the tourism industry of Matondang, 2016a: 5-7)) which can extend to regional levels in regional Asia and global (Matondang, 2016b).

In addition to cultural festival performances (Matondang and Butsi, 2016), traditional culinary delights from various provinces are vital for the tourism industry (Matondang, Rahma and Haramain, 2020a). In 2012 UNWTO recorded the proportion of culinary tourism services in the world is $34 \%$, then this institution predicted the growth trend of culinary tourism increased. The phenomenon of the rise of traditional culinary (Guptill, et al, 2017 and Ian, et al., 2015) strengthened the community based tourism model. It is one of the social capital for the development of the national tourism industry to a global level. The rise of ethnic cuisine from the late 1970s to 1980s in the United States (Guptill et al., 2017) and continued by the widespread culinary production in the United States was amazing thing. It made ethnic cuisines in the tourism industry play an important role.

Social strengthening through the management of the tourism industry based on local communities is a cultural capital (Matondang, 2016a) which is basically owned by each district or city in Indonesia. The regional tourism industry can foster economic, cultural revival and local products into a culinary business. In addition to natural resources, cultural festivals, historical monuments and handicraft products, the potential for fast-growing ethnic gastronomy into a modern culinary business is an essential factor in the tourism industry to be able to reach Asia and global. 
This primary research refers to previous research that focuses on the food products as an essential factor in the community-based tourism industry (Kivela \& Crotts, 2004). It sought the potentials ethnic food. For example, it noted that the phenomenon of pintxo from the cake in the Spanish Basque Country succeed in increasing the attractiveness of travelers come to Barcelona (Londoño, et al, 2018). Further, ethnic food of North Sumatra grew fast with application technology (Matondang, Rahma, and Haramain, 2020a).

Refer to the phenomenon of fast-growth of traditional food in Indonesia; this basic research is mainly to seek the data of the ethnic food that has evolved into the off and online-based culinary business. It was mapping the potential of North Sumatra Province's traditional culinary for the tourism industry. This research focuses on the ethnic food products as potent of Community Based Culinary Tourism of North Sumatra Province, Indonesia. The empirical data seeking was designed to find a new model for the culinary policy for the tourism industry.

\section{Method}

A qualitative approach was applied with the Science, Technology and Society (STS) (Woodhouse, 2014). The reason for choosing the STS model is the construction of this basic research related to the correlation and impact of science and technology on the socio-cultural community groups (Bibri, 2015). Technology construction on the social behaviour of the Community is observed to be a case study to produce the empirical data and mapping of social conditions in a particular time (Bibri, 2015 and Woodhouse, 2014). Observation and in-depth interview techniques for online-based culinary businesses were applied for data collection in North Sumatra Province. The Multi-sited Ethnography technique (Marcus, 1995 \& 1998) was used to observe the ethnic food and its growth from 2016 to 2019 in various production locations. The study selected all online-based traditional culinary entrepreneurs in North Sumatra Province as research subjects. With the Purposive Sample Technique, this study took 120 ethnic food entrepreneurs based on Community Based Tourism. 


\section{Data and Discussion}

\section{Data Obtained}

Data collection files the ethnic community factor in culinary products. Data gathering sought the degree of community bonds for ethnic food creation to produce menus affects the food tourism. Data obtained of North Sumatra ethnic food (Matondang, et al 2020b) revealed that the excellence of culinary products grow and some of them could be as an attraction for tourists to come again. So strengthen the cultural characteristics and regional identity of food products (Everett and Aitchison, 2008) required a Hub Information Project. Such ethnic food Hub is marketing the superior products to travel agents abroad and tourists. Then, the food and beverage industry in Indonesia grew 9.23\% and contributed to 34.33\% non-oil GDP in 2017 (https://finance.detik.com/industri/d-3985814/ April 2018). In relation to UNWTO's recommendation for culinary tourism; namely: analysis of destination positioning, and competitors and Benchmark to create a sustainable gastronomy tourism plan (2012). Those three things are for the development of the tourism industry.

In Community Based Tourism (Brătucu, et al. (2017) it found that the transformation of good food from local ethnic gastronomy produces many types of menus in the modern culinary. Food production in the advanced industrial system has been extended to convenient cuisines for the hospitality and tourism sector. Fieldwork to survey 120 ethnic food providers and culinary business owners in North Sumatra Indonesia results in the ranges of community bonds based on the socio-cultural factors such as language, Kinship, Cuisines, Memory, Filial, and Peers. The 120 samples community bonds in table 1 . The following tables are the responses of samples in the ranges from $45-100$.

Table 1: Community Bonds of Food Providers, Culinary Business Owners

\begin{tabular}{|c|c|c|c|}
\hline No \& Factors & $\begin{array}{c}\text { First } \\
\text { Generation } \\
(\mathbf{N = 4 0})\end{array}$ & $\begin{array}{r}\text { Second } \\
\text { Generation } \\
(\mathbf{N = 4 0})\end{array}$ & $\begin{array}{c}\text { Third } \\
\text { Generation } \\
\mathbf{( N = 4 0 )}\end{array}$ \\
\hline 1. Language & $80-100$ & $50-80$ & $50-70$ \\
\hline 2. Kinship & $85-95$ & $45-70$ & $45-65$ \\
\hline 3. Cuisines & $80-98$ & $70-85$ & $70-90$ \\
\hline 4. Memory & $60-90$ & $60-70$ & $50-70$ \\
\hline
\end{tabular}




\begin{tabular}{|l|l|l|l|}
\hline 5. Filial & $70-90$ & $70-80$ & $60-70$ \\
\hline 6. Peers & $60-75$ & $70-85$ & $60-70$ \\
\hline
\end{tabular}

Data on table 1, no 3, shows that the community bonds for cuisines for all generation are still high (80-98; 70-85; and 70-90). It implies that ethnic food is even placed in the vital factor for community bonds. The ethnic food attracts all generation to maintain the intangible cultural heritage.

Table 2: Special Ethnic Food Menus

\begin{tabular}{|l|l|l|}
\hline No & Ethnic Groups & \multicolumn{1}{|c|}{ Ethnic Food } \\
\hline $\mathbf{1 .}$ & Malay & Rice, fish curry, \\
\hline $\mathbf{2 .}$ & Karo & Rice, chicken cipera curry, \\
\hline $\mathbf{3 .}$ & Mandailing & $\begin{array}{l}\text { Rice, river fish, chicken } \\
\text { curry, ubi tumbuk/cassava } \\
\text { pressed leaves }\end{array}$ \\
\hline $\mathbf{4 .}$ & Toba & $\begin{array}{l}\text { Rice, pork, naniura fish } \\
\text { (uncooked) }\end{array}$ \\
\hline $\mathbf{5 .}$ & Simalungun & Rice, chicken curry, pork, \\
\hline $\mathbf{6 .}$ & Aceh & $\begin{array}{l}\text { Rice, Tongkol fish curry, } \\
\text { noodle, }\end{array}$ \\
\hline $\mathbf{5 .}$ & Minang & $\begin{array}{l}\text { Rice, rendang/meat, chicken } \\
\text { sate }\end{array}$ \\
\hline
\end{tabular}

Data table 2 shows that many kinds of ethnic food still attract buyers in North Sumatera Province. It made the market growth of ethnic food and beverages was tremendously increasing from 2016-2019. The use of ethnic community was found to maximize the ethnic cuisine ingredients for branding the North Sumatra's special cuisines. It has lead the tourism sector revenues increased from 2016 to 2019. The ethnic gastronomy can continue to make the growth of online culinary businesses doubled from 2016 to 2019 (3 years).

\section{Discussion}

Interpretation of data set of the observation on food supply chains noted that both village farmers and food producers in industries make the process of transformation in providing world food needs. Labeling culinary products as ethnic food is one of the marketing strategies. Many food products now are categorized as ethnic community 
creations; it doubles the appetizers of customers to order them. By maximizing the ethnic food of North Sumatra, it found that the regional labeled cuisines growing faster. Ethnic Community plays the important role to boost the ethnic food either in home country or international market places. Besides, the identity of ethnic food tends to increases the specialty of ethnic food has made the sustainability of ethnic heritage. Food search results in an online culinary model found hundreds of menus in the online system such as grab food, go-food, and Face book. Community-Based Tourism with application technology makes a potential local food menu appear in the e-commerce system. Community -Based culinary tourism factor made some changes for ethnic food production and business model. It notes that the culinary business now uses digital food marketing and delivery (Matondang, Rahma and Haramain 2020b). Ethnic Community helps members to join the application technology which sustains the development of the potential for local gastronomy in the tourism industry concerns the efforts of all stakeholders to attract more tourists to enjoy the ethnic food and their derivatives; it was an excellent quality for food visitors. Markets demand leads the ethnic community to provide the culinary tourism actors and this paradigm change requires creative collaborative work.

Interpretation of transformation of food tourism in North Sumatra shows that the potentials food creation intensifies the star ups to highlight unexplored recipes. It revealed the Community Based Tourism makes the limited capacity of Small and Medium Enterprises (SMEs) in North Sumatra reached better food expertise and high technology. There are new challenges to providing better services. Knowledge, technology and skills also contribute to the exploration of local natural resources. It was found that although many owners and managers were initially a little concerned about the effectiveness of the online system (Matondang, Rahma \& Haramain, 2000b). Community -Based Tourism led the food creation of local food specialists. Thus, an integrated strategy of gastronomy tourism is to increase the ethnic food market. Also ethnic food factors play an essential role in the motivation of tourists coming to from Malaysia to Indonesia. In tourist cities or cities due to application technology, new mixed food and beverage menus are available in an online system to support conventional markets (buyers come to restaurants and cafes). 
Picture 1: Transformation of culinary tourism

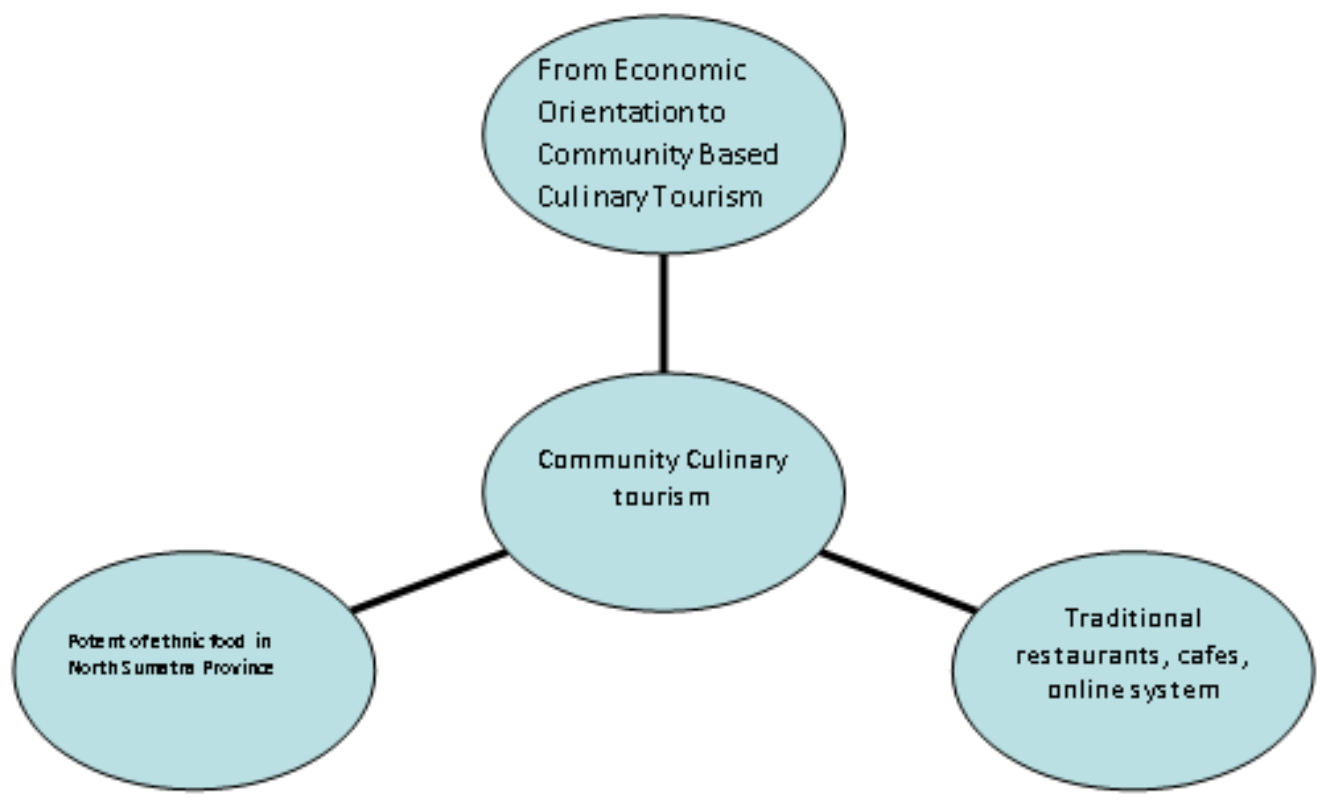

Data of Picture 1 displays the paradigm of culinary tourism transformation. Community -Based culinary tourism factor made some changes for ethnic food production and business model.

\section{Conclusions}

The data interpretation of Community Based Culinary Tourism Model in North Sumatra context, it gives two conclusions;

(1). with culinary labeling products as ethnic food makes the community bonds and associations increases. It is one of the marketing strategies of food producers for traditional gastronomy business. Ethnic food as a label in modern marketing may refer to any product that has been cultivated, to be processed and distributed in the location where the customer or buyer lives

(2). the transformation of good food from local ethnic gastronomy produces many types of menus in the modern culinary business. Ethnic food is attracted to the emotions of customers to buy it. Food production in the advanced industrial system has been extended to food that is convenient for the hospitality and tourism sector. 


\section{Disclosure statement}

No potential conflict of interest was reported by the authors.

Contact Information

E-mail: siti@gmail.com 
References and notes:

Anuar, ANA, and Mohd Sood, NAAM.2017. Community-Based Tourism: Understanding, Benefits and Challenges. J Tourism Hospitality, vol.6: 263. DOI: 10.4172/21670269.1000263

Bibri, S.E.2015. The Shaping of Ambient Intelligence and the Internet of Things, Ambient and Pervasive Intelligence 10:Atlantis Press: USA

Brătucu , CG, et al. 2017. Approaching the Sustainable Development Practices in Mountain Tourism in the Romanian, Sustainability Vol, 9, 2051; DOI:10.3390/su9112051

Detikcomfinancial. 2018. Menperin: Industri Makanan dan Minuman Tumbuh 9,23\%/detikcom finance/ https://finance.detik.com/industri/d-3985814/menperin-industri-makanandan-minuman-tumbuh-923 Senin, 23 Apr 2018 13:11 WIB

Giordano, Christian. 2015. Power Legitimacy, Historical Legacies, A disenchanted Political Anthropology, LIT Verlag: Zurich

Guptill, et all. 2017. Food and Society: Principles and Paradoxes. Polity Press Cambridge

Kivela, Jakša \& Crotts J. 2004.Tourism and Gastronomy: Gastronomy influence on how Tourists Experience a Destination, Journal of Hospitality \& Tourism Research, Vol. 30, No. 3, August 2006, 354-377 DOI: 10.1177/1096348006286797

Londoño, et all .2018. Gastronomy and tourism: blending local essence and global logic: The case of Basque taverns in Barcelona's El Poble Sec neighbourhood, Anthropology of Food, Vol. $13 / 19$

Marcus, G. 1995. Ethnography in/of the world system: The emergence of multi-sited ethnography. Annual Review of Anthropology 24: 95-117.

Marcus, G. 1998. Ethnography through thick and thin. Princeton: Princeton University Press.

Matondang, S A dan Setiawan, Y.2015. Teori Kebudayaan: Interaksi Lokal dengan Wisata Regional dan Global, PT Perdana Handal: Medan.

Matondang, SA and Butsi, Febry I. 2020. Heritage Tourism Creativity in the Forms of Urban Festival for Global Industry, International Journal of Advanced Science and Technology, 29 (6).pp- 1803-1810

Matondang, SA dan Butsi, FI. 2016. Perhelatan Ritual, Karnaval, dan festival kultural”Polyethnic City “ KotaMedan untuk Pembangunan Industri Wisata Global , Laporan Hibah Fundamental, Kemenristek Dikti

Matondang, SA, Rahma S, Haramain, T.2020a. The Online Culinary Business of North Sumatra, International Journal of Advanced Science and Technology, 29 (6s), pp 692-701

Matondang, SA, Rahma, S \& Haramain, T. 2000b. Digital Food Marketing and Delivery of Ethnic Food Impacts on Culinary Business, Talent Development and Excellence Journal, 12 (2s) pp-1231-1236

Matondang, SA. 2016a. Celebrating the local traditions for global heritage tourism, International Humanities Studies, 3: 1. March 2016 (5)

Matondang,S A. 2016b. The Social Dramas of Ethnoregional South East Asian in Globalism: Recasting cultural heritage for Ethnic Revivals, University of Fribourg Switzerland

Salazar, N B .2012. Community-based cultural tourism: issues, threats and opportunities. Salaza Journal of Sustainable Tourism Vol. 20, No. 1, January 2012, 9-22

UNWTO .2012 . Global Report on Food Tourism. Madrid: UNWTO publications.

Woodhouse, Edward. 2014. Science Technology and Society (1st ed.). San Diego: University Readers.

\section{Acknowledgement:}

This research grant is funded by Ministry of Research and Technology of Indonesia (Basic Research Scheme 20219-2020). 